УДК 811.111

DOI: 10.37026/2520-6427-2019-99-3-102-105
Наталія КВАСНЕЦЬКА, кандидатка педагогічних наук, доцентка кафедри методики викладання іноземних мов Рівненського державного гуманітарного університету

Ірина РУДь, студентка магістратури факультету іноземної філології

Рівненського державного гуманітарного університету

\title{
НАВЧАННЯ СТАРШОКЛАСНИКІВ АВТЕНТИЧНОГО РОЗМОВНОГО МОВЛЕННЯ НА ОСНОВІ ХУДОЖНІХ ТЕКСТІВ
}

У статті доведено значущість використання автентичних художніх текстів під час навчання учнів-старшокласників іноземної мови. Запропоновано приклади вправ, які допоможуть на уроці в опраџฺюванні автентичного тексту.

Ключові слова: автентичний художній текст, комунікативна компетенція, розмовне мовлення, соціокультурні знання.

В статье проанализирована значимость использования аутентичных художественных текстов при обучении учашихся-старшеклассников иностранному языку. Предложено примеры упражнений, которые помогут на уроке в обработке аутентичного текста.

Ключевые слова: аутентичный художественныий текст, коммуникативная компетенция, разговорная речь, социокультурные знания.

The article analyzes the significance of the use of authentic texts in the study of a foreign language, and especially in the development of communicative competence of students. It shows us some examples of exercises that will help to work with the authentic text, based on the language practice of students in the classroom. Considerable attention is paid to the study of linguistic and communicative features of the English spoken language, which is characterized by the use of colloquial vocabulary and phraseology, mainly short, simple syntactic constructions, expressive intonation, in the formation of linguistic and sociocultural competence in teaching English.

We have characterized the advantages of using authentic texts to form the communicative and socio-cultural competence of high school pupils during English lessons. The use of authentic English texts in the process of learning English is promoted by: increases communicative and cognitive abilities, which as a consequence increase motivation of students; positive influence on the person-emotional state of students; providing possibility of contemporary appeal to the language and culture; formation of socio-cultural competence.

We have suggested a list of exercises for learning English spoken language on the basis of authentic artistic texts. The combination of exercises proposed in the research provides the consistent and gradual formation of lexical-grammatical skills in the use of lexical units of English spoken language and should help students learn new material. The article concludes that it is necessary to introduce the use of authentic materials in the lessons.

Development of approaches, ways and methods for working with authentic texts on English lessons is possible in further research.

Key words: authentic text, communicative competence, lexical-grammatical skills, socio-cultural competence, spoken language.

Постановка проблеми. Основною рисою у вивченні мови $є$ не лише володіння її лексичними одиницями чи граматичними конструкціями, а передусім уміння спілкуватися. Саме в спілкуванні відображається і рівень засвоєння вивчених лексичних одиниць, і здатність правильно застосувати певну граматичну конструкцію. У ході вивчення іноземної мови в немовному середовищі навіть в учнів із високим рівнем знань у ході спілкування виникають неабиякі труднощі.

Робота 3 автентичними текстами відіграє ключову роль у пізнанні культури країни, мова якої вивчається, у створенні мотивації, підтриманні інтересу, забезпеченні взаємозв'язку навчання із життям. Саме тому автентичні художні тексти мають стати ефективним засобом вивчення іноземної мови, який варто практикувати вчителям на уроках у старших класах. 
Аналіз наукових досліджень і публікацій. Дослідження науковців (Н. Баришніков, Г. Вороніна, Г. Жогліна, О. Ігна, К. Кричевська, Р. Мильруд, Е. Носоновіч, М. Плеханова, Н. Хорунжа, М. Breen, Ch. Edelhoff, J. Harmer, H. Hofmann, L. Lier, G. Neuner, R. Scarcella, D. Wilkins та ін.) свідчать, що робота учнів із різними видами автентичних текстів сприяє підвищенню їх комунікативно-пізнавальної мотивації, формуванню лінгвокраїнознавчої та міжкультурної компетенцій, позитивно впливає на індивідуально-емоційний розвиток школярів, забезпечує можливість одночасного звернення до мови і культури країни. Питання використання автентичних текстів у процесі навчання учнів іноземної мови є предметом досліджень таких учених-педагогів, як А. Бабайлова, Н. Бориско, Н. Ішханян, О. Вишневський, І. Комарова, Д. Малявін [5], Л. Морська, А. Неділько, А. Пелишенко, Л. Смелякова, О. Шерстюк та ін.

Відзначаючи значний доробок учених у розкритті особливостей використання автентичних текстів у цілому, вважаємо за доцільне продовжити вивчення впливу автентичних художніх текстів на розмовне мовлення учнів.

Мета статті - окреслити особливості використання автентичних художніх текстів як джерела формування комунікативної та соціокультурної компетенцій учнів-старшокласників на уроках іноземної мови у закладах загальної середньої освіти.

Виклад основного матеріалу. Формування іншомовної комунікативної компетенції відбувається в процесі навчання спілкування, оскільки в дискурсах представлені мовні висловлювання комунікантів. Таким чином, для формування означеного виду компетенції, а також для того, щоб на уроках іноземної мови максимально наблизити мову школярів до повсякденної та літературної норми суспільства, мову якого вони вивчають, методисти (М. Брін, Л. Ліер, С. Ніколаєва, Г. Ноейр, О. Шерстюк, McDonough, Morrow, Phillips, Wilkins та ін.) пропонують здійснювати означений процес, використовуючи автентичні художні тексти [4].

Як зазначається в Рекомендаціях Ради Свропи, «автентичний текст є основою будь-якого акту мовленнєвого спілкування, зовнішньо предметною, поєднувальною ланкою між тим, хто продукує, та тим, хто сприймає, незалежно від того, спілкуються вони безпосередньо чи на відстані» [3].

Поняття «автентичність» у методиці навчання іноземної мови трактується як «застосування автентичного мовного та мовленнєвого матеріалу в процесі навчання». Оригінальні тексти характеризуються сукупністю особливостей, які повинні бути використані як зразок для розвитку вмінь і навичок експресивного мовлення (як діалогічного, так і монологічного) [6]. Використання таких текстів позитивно впливає на організацію занять з іноземної мови, адже при цьому фіксуються мовленнєві та структурні особливості розмовно-літературного мовлення, відображаються найбільш характерні лексико-граматичні та стилістичні зміни, наявні в мові [2].

Оскільки в оригінальних текстах спостерігається максимальне наближення мови персонажів до зразків розмовно-літературного мовлення, оригінальні тексти можуть бути використані не лише як джерело мовної інформації, а й як ілюстративний матеріал ситуативно-обумовленого використання лексичних одиниць та граматичних явищ. Крім того, тут представлені різноманітні ситуації спілкування, завдяки яким учням можна проілюструвати, наприклад, як умови спілкування впливають на побудову висловлювання [5].

У лінгвістичному аспекті автентичні тексти характеризуються неабиякою своєрідністю лексики. Зокрема, в них наявні вигуки (Watch out!, Be careful!, Get along with you! From «Alice's Adventures in Wonderland» by Lewis Carroll), фразеологізми (never say die, a bag of bones from «Oliver Twist» by Charles Dickens), ідіоми (growing rather red, as white as snow, grew white from «The Picture of Dorian Gray» by Oscar Wilde), а також займенники, частки, слова з емоційним забарвленням, мовні кліше тощо. Матеріали автентичного характеру забезпечують соціокультурну спрямованість навчання, оскільки такий текст містить інформацію про культуру країни, мова якої вивчається, відображає їі національну специфіку.

Таким чином, автентичний текст містить нову інформацію, що є значущою для учнів за умови, якщо зміст тексту відповідає їх потребам, уподобанням та інтересам, оскільки саме такий текст викликає в суб'єктів навчання відповідну реакцію, стимулює розумову діяльність. Використання автентичних текстів у процесі навчання іноземної мови дає учням можливість отримати цікаву інформацію, збагативши таким чином свої соціокультурні знання про життя носіїв мови та розвинувши вміння читання іншомовних текстів. Саме автентичний текст, на нашу думку, як ніякий інший, допомагає зрозуміти національну специфіку та культуру країни, мова якої вивчається, поповнити свій словниковий запас новими словами і виразами.

Як відомо, навчання іноземної мови буде ефективним лише за умови використання достатнього запасу іншомовних слів, до складу якого входять найбільш комунікативно значущі одиниці. Поступово, удосконалюючи вміння іншомовного спілкування, учень збільшує обсяг власних висловлювань, активізує наявний лексичний і граматичний матеріал, унаслідок чого процес навчання стає успішнішим i продуктивнішим.

Оригінальні тексти, наприклад, такі, як «Масbeth», «Hamlet», «King Lear» by Shakespeare, «The Picture of Dorian Gray» by Oscar Wilde, «Ivanhoe» by Walter Scott, можуть слугувати зразками для адекватної мовленнєвої поведінки в різних ситуаціях спілкування. Завдяки системній роботі 3 автентичним матеріалом на уроці усі без винятку учні можуть повправлятися в усному мовленні. При цьому активізується розумова діяльність школярів, підвищується їхн мотивація та загальний інтерес до країни, мову якої вони вивчають, розвивається здатність до спілкування, заняття перетворюються на цікавий і захоплюючий процес, під час якого діти здобувають нові знання.

Варто зауважити, що робота з автентичними текстами має певну специфіку та включає такі основні етапи:

1. Розпізнавання змісту тексту - визначення композиції, виявлення сутності змісту, критичне сприйняття, виокремлення головного і другорядного.

2. Аналіз розуміння змісту тексту - створення асоціативного ряду, інтерпретація та узагальнення. 
3. Робота над змістом тексту.

Зважаючи на вищевикладене, для прикладу, учням можна запропонувати такі вправи для роботи 3 автентичним текстом:

\section{Pre-reading activities.}

1. Answer the following questions:

- What associations arise after reading the title of this text?

- What do you think this text is about?

- Where does this text come from? - from the novel; from the diary; from the magazine; from the newspaper.

2. The teacher writes a keyword on the board. Students should pick up associations that they will write on the board. Then the text, which refers to the abovementioned word, is given to the students. They read and translate it.

\section{While-reading activities.}

1. Students receive the text for translation and work in three subgroups. One subgroup works without a dictionary, the second - with a monolingual dictionary, the third - with a bilingual dictionary. After all, all three versions of the translation are discussed.

2. Students work with the text in which the words are missed. They work in groups of two and fill in the omissions by their own. After the list with the missing words, which are arranged in alphabetical order is given.

3. Teacher prepares several texts, cuts and mixes. Students work in small groups and retrieve texts in the required sequence.

\section{Post-reading activities.}

1. Students read the proposed text without a title. After reading, give their own titles to the text.

2. Students are given a text consisting of 20-30 sentences. Students read the text and shorten it to ten sentences.

Сьогодні, у час розвитку інтернет-технологій, на уроках іноземної мови доречним буде використання матеріалів, спеціально розроблених фахівцями та розміщених на інтернет-сайтах (наприклад, TeachingEnglish - https://www.teachingenglish.org.uk/; BBC Learning Zone - https://www.bbc.co.uk/programmes/ p01b8f09 тощо).

Інтегровану демонстрацію мовлення з урахуванням позамовних факторів забезпечує використання технічних засобів навчання. Таке використання автентичних текстів у поєднанні з технічними засобами (відеододатки до зарубіжних підручників; художні фільми, зокрема й серіали, дія в яких відбувається в країні, мова якої вивчається, навчальні фільми та телепрограми) є надзвичайно ефективним на уроках іноземної мови. Таким чином, щоб з'ясувати специфіку поведінки носіїв мови, а також обставини, в яких відбувається акт спілкування (магазин, метро, аеропорт, навчальна аудиторія, театр тощо), їх необхідно бачити. Основний акцент при цьому робиться на підготовку учнів до участі в процесі спілкування англійською мовою, тобто на вдосконалення вміння враховувати національно-культурну специфіку вербальної та невербальної комунікативної поведінки, вміння запобігти культурним конфліктам, які можуть виникнути, зважаючи на відмінності у цінностях й етносоціокультурних установках у власній культурі та культурі носіїв іноземної мови. Отже, без знань соціокультурного фону неможливо сформувати комунікативну компетенцію. Лише культура в різних іiі проявах сприяє формуванню особистості [2].
Вільне володіння старшокласниками іноземною мовою, здатність розуміти висловлювання співрозмовника та відповідати на нього є не лише умовою їх успішної взаємодії з іноземцями в різних сфеpax суспільного життя, а й сприятиме швидшому досягненню ними успіху в майбутній професійній діяльності.

Висновки. Зважаючи на викладене вище, зауважимо, що автентичні художні тексти - неодмінна й важлива складова у навчанні учнів іноземної мови, зокрема й англійської розмовної. Використання автентичних текстів у навчальному процесі забезпечує зростання пізнавальної активності школярів, розширює їхні комунікативні вміння, забезпечує активність та особисту зацікавленість на занятті, знайомить із цінностями культур інших народів, спонукає накопиченню досвіду у спілкуванні, сприяє самостійній роботі над мовою, вихованню толерантності до інших культур, манер поведінки, звичаїв та традицій, формує власне бачення світу та своє місце в ньому й, зрештою, на цій основі забезпечує формування соціокультурної компетенції.

Перспективи подальших досліджень у даному напрямі вбачаємо в пошуку нових способів подачі автентичних художніх текстів на уроці іноземної мови 3 метою ефективного розвитку комунікативної компетенції учнів-старшокласників.

\section{СПИСОК ВИКОРИСТАНОӤ ЛІТЕРАТУРИ}

1. Девкин В.Д. Особенности разговорной речи / В. Д. Девкин. - М. : Международные отношения, 1965. -670 с.

2. Державний освітній стандарт з іноземної мови (загальна середня освіта). V - IX класи / кер. автор. кол. С. Ю. Ніколаєва. - К. : Ленвіт, 1998. - 38 с.

3. Загальноєвропейські рекомендації 3 мовної освіти: вивчення, викладання, оцінювання / за наук. ред. С. Ю. Ніколаєвої. - К. : Ленвіт, 2003. - 273 с.

4. Ізмайлова О. А. Роль автентичного тексту у формуванні дискурсивної компетенції студентів мовних спеціальностей / О. А. Ізмайлова // Збірник наукових праць [Херсонського державного університету]. - 2013. - Вип. 63. - С. 279-283. - (Серія «Педагогічні науки»). URL: http://nbuv.gov.ua/UJRN/ znppn 20136358 (дата звернення: 15.06.2019).

5. Комунікативні методи та матеріали для викладання англійської мови: ознайомлювальна брошура для українських учителів англійської мови / перекл. з англ. Л. В. Биркун. - Oxford University Press, 1998. C. 7-8.

6. Пелишенко А. С. Использование аутентичного песенного материала в обучении иностранным языкам / А. С. Пелишко // Іноземні мови. - 1995. № 3 - 4. - C. 33-36.

7. Рогова Г. В. Методика обучения иностранным языкам в средней школе / Г. В. Рогова, Ф. М. Рабинович, Т. Е. Сахарова. - Москва : Просвещение, 1991. $287 \mathrm{c}$.

8. Рудь I. О. Етапи роботи з автентичним текстом на уроках іноземної мови в старших класах / I. О. Рудь // Актуальні проблеми сучасної іноземної філології : студентський науковий вісник. - Рівне : РДГУ, 2018. - С. 226- 229.

Дата надходження до редакиіï: 11.07.2019 р. 